\title{
OLDER PEOPLE AS A SUBJECT OF RESEARCH ON THE INFORMATION SOCIETY
}

\author{
Ewa Frąckiewicz ${ }^{\square}$ \\ University of Szczecin, Poland
}

\begin{abstract}
The aim of the article is to present the legitimacy and conditions of research on seniors and its challenges in the context of further development of the information society (IS). The conducted considerations lead to the conclusion that research of this nature is limited by the lack of unambiguity in the concept of elderly persons and the information society. Nevertheless, it has been argued that studies of older people as members of the IS are fully justified by the importance of this group in society as a whole. Whereas analysis conducted on those aged 60 years and over, or 65 years and over, is insufficient. Older people should be analyzed in smaller age ranges and the analyses require both quantitative and qualitative approaches. Qualitative approaches improve our understanding of the reasons that new technologies are used or rejected, which can help to achieve one of the goals of IS development - to increase the quality of life for seniors in the future.
\end{abstract}

Key words: older people, senior research, information society

JEL codes: J14, O33

\section{INTRODUCTION}

The changes taking place in market relations is resulting in a growing demand for information. Nowadays, it is an indispensable resource enabling economic and social development, which characterizes the information society (IS). The primary source and access channel to information is found in ICT solutions (Information and Communication Technologies, new technologies). They are devices and systems which are increasingly connected to the global Internet network. Among their users, the elderly constitute a relatively small group. Meanwhile, this group is becoming more and more numerous and at the same time increasing its share in the total population of most countries around the world, including Poland.
The aim of the article is to present the legitimacy and conditions of conducting research on seniors and its challenges in the context of further development of the information society. It was assumed that the diagnosis and assessment of the degree of IS development requires a broader and more in-depth study of older people than is currently the case. The paper was created on the basis of literature research in the field of economics, management, information economics, social policy, gerontology, studies of Polish and foreign governmental and non-governmental organizations and the author's many years of research and observation. 


\section{OLDER PEOPLE - DEFINITIONAL PROBLEMS}

A key issue at the stage of developing research among seniors is the very definition of the concept of an elderly person. Aging of the human body is its inevitable and natural. However, this process has a complex character. It results not only from the number of years lived; it also depends on lifestyle, diet, genetics, physical activity, nature of work, professed values, self-esteem and other factors. This means that individuals age at their own characteristic rate [Zboina 2008, p. 43]. It is simplistic to equate all older people as being infirm, dependent, non-working, inactive and stay-at-home people. Obviously, among seniors, people with such characteristics can be found more often than in younger groups. However, there are also groups of older people who exhibit different attitudes and behaviors. Błędowski points out that there are several important differences when comparing the social characteristics of old people years ago versus now in the 21 st century, including [Błędowski 2002, p. 106]:

- relatively rapid retirement, during a period of relatively high physical and intellectual fitness,

- a kind of "rejuvenation" of old age, manifested in a change in the attitude of the elderly towards themselves,

- relatively large share of this group in the total society,

- feminisation of old age,

- heterogeneity of the group of elderly people,

- evolution of old age patterns in social perception - from negative stereotypes to diversity.

As a consequence, indicating the moment at which a person should be classified as 'elderly' is very difficult. It would be necessary to conduct research at the level of each individual, taking into account the influence of biological, social and psychological factors. Measurement of these characteristics on the scale of the entire population seems to be impossible and unreasonable [Błędowski et al. 2012, pp. 45-47]. Hence, the calendar age, measured by the number of years lived from the day of birth, is used. It is the most universal and at the same time relatively simple and easy to apply. In particular, it allows for unambiguous determination of the moment of acquiring pension rights, which is identified with the moment that old age begins.
- However, in publications presenting the results of surveys conducted among seniors, one encounters different approaches to determining the age when old age actually begins. These different approaches can be seen in studies by such organisations as WHO, Eurostat or a country's Central Statistical Office. This is due to differences in the timing of the analyses, the research area, the availability of data or the possibility to make comparisons. The calendar age threshold for defining an elderly person is significantly different, e.g.:

- 50 years - Badowska [2016],

- 55 years - Bombol and Słaby [2011], Petrovic et al. [2018],

- 60 years - Kusińska [2002], Badowska and Rogala [2016], Olejniczak [2019], Dąbrowska et al. [2020], World Health Organization [WHO 2004], CSO,

- 65 years - Hough and Kobylanski [2009], Olson et al. [2011], Mossakowska, Więcek, and Błędowski [2012], Zalega [2016], CSO, Eurostat.

Taking into account the objective difficulties in defining an elderly person and the use of different age caesura, however, there is clearly an increase in interest in the attitudes and behaviors of older people. This is due to two main reasons: the growing number and share of seniors in the total population, and their relatively strong market position.

It is predicted that by the middle of the 21 st century, the number of people aged 60 and over will be three times higher than at the dawn of this millennium, and will number more than 2 billion people, i.e. $22 \%$ of the world population. The projected changes in the age structures of individual societies apply to all continents, although to different extents. In the perspective of 2050 , it is expected that the aging process will concern African countries to the least extent (increase in the number of people $60+$ from 6 to $10 \%$ ). On the other hand, South America will see the largest increase in the number of older people. Asia will be the continent inhabited by $2 / 3$ of the entire world population of seniors, while in the Oceania region the share of elderly people will not exceed 1\% [UNFPA and HelpAge International 2012].

Referring to the situation of countries in the European Union, it should be noted that while in 2000 all the member countries were characterized by a share 
of seniors not exceeding $20 \%$, in the mid-21st century only Luxembourg will remain in this group. While in as many as nine EU countries, every third resident will belong to the group of elderly people [Avramov and Maskova 2003, pp. 116-118]. At the same time there will be a decrease in the number and share of the youngest people: from $150,000(18.6 \%)$ to $105,710(14.7 \%)$.

Seniors create an attractive market, although mainly in highly developed countries. In the United States, in 2016, the $75+$ generation had wealth more than twice as much as the wealth of Generation X and 23 times as much as the wealth of Millennials. The net worth of a typical pensioner was USD 264,750 [Howe 2018]. In 2017, the average annual income of senior citizen worldwide was USD 14.5 thousand, nearly $20 \%$ higher than the global average (USD 12.3 thousand) [Batsaikhan 2017]. According to a report by Poland's Central Statistical Office (GUS), which has been monitoring the situation of households of elderly people since 2015, their income situation is better (albeit slightly) than that of households consisting only of younger people. In 2019, people aged 60 and over, living in households composed only of people of this age, had an average monthly disposable income per person of PLN 2,109. Compared to the previous year, it increased by PLN 139 (i.e. by 7.0\%) [GUS 2021]. Despite the significant diversification of the situation of seniors in developed and developing countries, the trend of increasing incomes of older people is forecast to continue. Euromonitor estimated their global purchasing power at USD 12 trillion in 2020.

Seniors are therefore becoming an increasingly important market for buyers of goods and services. Taking into account the purpose of this study, it should be emphasized that more and more products in general, including those whose clients are elderly people, are based on ICT solutions. The period of the SARS$\mathrm{CoV}-2$ pandemic even forced many of them to use new technologies.

\section{INFORMATION SOCIETY - AMBIGUOUS CONCEPT}

The concept of an information-driven society emerged as a result of the synergistic interaction of a complex set of political, technological, social, economic, and cultural factors in the 1960s. [Goliński 2013, pp. 96-97]. The spread of this idea took place as a result of the technological revolution which was initiated in the 1970s by an innovative product which was the microprocessor [Mansel et al. 2007]. The term information society is widely accepted today. However, it is worth noting that there are also other terms such as: post-industrial society [Bell 1976], third-wave society [Toffler 1985], knowledge society [Drucker 1993], network society [Castells 1996], that some authors believe to better describe the state or goal of development of society after the industrial age (Table 1).

Table 1. Selected differences between industrial and post-industrial society

\begin{tabular}{lcc}
\hline Dimensions & Industrial society & Post-industrial society \\
\hline Resources & energy & information \\
Technology & capital intensive & science intensive \\
Objective & game against nature & game between people \\
Basic form of economic activity & production of material goods & production of information \\
Markets & reasonably stable & dynamically variable \\
Consumption & mass & mass customization \\
Buyer's position & he can buy, he has a choice & has a wide selection, prosumer \\
Work & at the employer's premises & independent of the place \\
Communication & human-human & human-machine \\
Relations & human-machine & machine-machine \\
Education & personal, direct & indirect, virtual
\end{tabular}

Source: [Krzysztofek and Szczepański, 2005, p. 80, Czaja 2010, p. 45] and author's own research. 
IS is defined, for example, as "an information-rich society where information is available on demand" [Zacher 1992], "a society where information is a key element of socio-economic activity and change" [Casey 2001, p. 34], "a society that (broadly speaking) includes all people living in the area of impact of new technical solutions, using computers and communication means to a different extent" [Kęsy 2011, p. 76], "a society where information is used extensively in economic, social, cultural, and political life; a society that is rich in the means of communication and information processing, which form the basis of most of the national income and provide the livelihood of most people" [Krzysztofek and Szczepański 2005, p. 170]. These examples represent a variety of approaches. However, their common feature is that they emphasize the importance of information in all aspects of human activity.

Therefore, the concept of IS is not unambiguous, e.g. due to the perspective (technology, human) and the selected fragment of reality that is subject to research. It may refer to the technological, spatial, cultural and economic spheres [Dziuba 2001]. Not only is it interdisciplinary in nature, but, as Zacher points out, it is an unfinished phenomenon - indeed, it is constantly evolving and, moreover, unevenly developing in individual societies [Zacher 2007, p. 52-56].

The development of IS was initially assessed almost unambiguously positively once the basic condition of availability was fulfilled. At present, threats related to the development of IS for the general public and its individual units are also clearly visible. Hence, the observation covers, for example, the risk of loss of privacy, cybercrime, inability to interpret information, addiction to ICT, dissemination of untrue or unverified information. As a consequence, different researchers and organizations use different sets of indicators and measures, ranging from a dozen to several dozen items. They refer to different spheres at macro, meso and micro levels, including households and individuals. Goliński proposed to divide them into quantitative and qualitative, supply and demand, hard and soft [Goliński 2013, p. 156]. He rightly pointed out that they indicate certain phenomena to a greater extent than explain their nature and causes.

\section{ELDERLY PEOPLE IN THE INFORMATION SOCIETY}

Despite the lack of a single definition defining the concept of information society and even criticism of this concept [Castells 2007, Golinski 2009, Czaja 2010] the IS development process from the perspective of individual users can be analyzed in four areas that reflect successive levels of IS development:

- access and type of ICT,

- the way ICT is used,

- type of activities carried out in ICT,

- ICT skills.

Each of these areas can be assigned different types of measures, which may additionally refer to different spheres of life. Eurostat, in the information society section, groups them by types of devices, types of activity, skill levels, nature of problems encountered, etc. Eurostat also successively adds new ones (e.g. Internet of things). The available databases allow data to be analysed by many age ranges, starting with the group of 15 years and younger. The group of the oldest IS members can be analyzed in the ranges: $55-64,65-74$, and 75 years and older. This means that the application of the 60 years threshold is not possible. However, in the case of the study of Polish seniors, the age of 60 is justified. It is closer to the actual age of retirement (for women it is 60.6 , for men: 62.8) [OECD 2018].

Using the approach used by Eurostat in diagnosing the development of the information society, Table 2 presents the characteristics of the elderly population in Poland according to selected criteria. The two oldest groups of people considered by Eurostat are those aged 65 to 74, and 75 and over. Despite the distinction of the latter group, few countries conduct such surveys. For example, for Internet use, only Spain, Ireland, Italy and Norway within the EU. Norway is characterized by a very high share of Internet users among people 75 years and older. In 2020, $76 \%$ of these people had used the global network in the past 12 months [Eurostat 2021].

Older adults participate in the same research as the general population. The research has the same purpose and is based on the same research tool. However, two aspects are worth pointing out: 
Boboli, I., Muça, E., (Dashi). (2021). Exploring tourist expenditures of the gjirokastra district in Albania: a cluster analysis. Acta Sci. Pol. Oeconomia 20 (2), 31-38, doi: 10.22630/ASPE.2021.20.2.13

Table 2. Levels of advancement of IS development and selected data characterizing seniors in Poland (\%)

\begin{tabular}{|c|c|c|c|c|c|}
\hline $\begin{array}{l}\text { Category } \\
\text { (year) }\end{array}$ & Example & $\begin{array}{l}\text { General } \\
\text { population } \\
\text { (a) }\end{array}$ & $\begin{array}{l}\text { 65-74 } \\
\text { years old } \\
\text { (b) }\end{array}$ & (a)-(b) & $\begin{array}{l}75 \text { years } \\
\text { old and } \\
\text { more }\end{array}$ \\
\hline \multicolumn{6}{|c|}{ Level 1 - access and type of ICT } \\
\hline \multirow{2}{*}{$\begin{array}{l}\text { Computer use } \\
(2017)\end{array}$} & last computer use* within last 12 months & 77 & 31 & 46 & $*$ \\
\hline & never & 19 & 62 & -43 & $*$ \\
\hline \multirow{2}{*}{$\begin{array}{l}\text { Internet use } \\
(2020)\end{array}$} & last internet use* in the last 3 months & 83 & 43 & 40 & $*$ \\
\hline & last internet use* more than a year or never & 15 & 54 & -39 & $*$ \\
\hline \multicolumn{6}{|c|}{ Level 2 - the way ICT is used } \\
\hline \multirow{2}{*}{$\begin{array}{l}\text { Frequency of internet use } \\
(2020)\end{array}$} & daily & 72 & 28 & 44 & $*$ \\
\hline & at least once a month & * & * & - & $*$ \\
\hline \multirow{2}{*}{$\begin{array}{l}\text { Devices used to access } \\
\text { the internet } \\
\text { (2018) }\end{array}$} & tablet & 15 & 4 & 11 & $*$ \\
\hline & mobile devices & 73 & 27 & 46 & $*$ \\
\hline \multicolumn{6}{|c|}{ Level 3 - type of activities carried out in ICT } \\
\hline \multirow{2}{*}{$\begin{array}{l}\text { e-commerce } \\
(2019)\end{array}$} & last online purchase* in the last 12 months & 61 & 17 & 44 & $*$ \\
\hline & $\begin{array}{l}\text { individuals carried out at least one of the finan- } \\
\text { cial activities over the internet }\end{array}$ & 7 & 2 & 5 & $*$ \\
\hline \multirow{2}{*}{$\begin{array}{l}\text { e-government } \\
(2020)\end{array}$} & $\begin{array}{l}\text { interaction with public authorities (last } 12 \text { mon- } \\
\text { ths) }\end{array}$ & 42 & 13 & 29 & $*$ \\
\hline & $\begin{array}{l}\text { submitting income tax declaration via website of } \\
\text { public authorities }\end{array}$ & * & * & - & $*$ \\
\hline \multicolumn{6}{|c|}{ Level 4 - ICT skills } \\
\hline \multirow{2}{*}{$\begin{array}{l}\text { Digital skills } \\
(2018)\end{array}$} & individuals who have basic overall digital skills & 23 & 7 & 16 & $*$ \\
\hline & $\begin{array}{l}\text { individuals carried out free online training or } \\
\text { self-study }\end{array}$ & 6 & 1 & 5 & $*$ \\
\hline \multirow{2}{*}{$\begin{array}{l}\text { ICT trust, security and } \\
\text { privacy } \\
(2020)\end{array}$} & $\begin{array}{l}\text { individuals don't know if their smartphone has } \\
\text { some security system }\end{array}$ & 15 & 13 & 2 & $*$ \\
\hline & $\begin{array}{l}\text { individuals at least once restricted or refused } \\
\text { access to personal data }\end{array}$ & 46 & 11 & 35 & $*$ \\
\hline
\end{tabular}

\section{* - not available}

Source: author's own research based on [Eurostat 2021].

- younger people are surveyed in more numerous and smaller age ranges (up to 15 years, 16-19 years, 20-24 years, 25-29 years), while older people are surveyed in three ranges (if it is assumed that an older person is the one aged 55) or in two, i.e. 65-74 and 75 years and over;
- there are very limited, unavailable, or unreliable results for those over 74 .

Combining respondents aged e.g. 60 and 73 in one group, as well as creating a group of people aged 65 and over, is certainly convenient. However, it should be noted that such an approach will be less and less 
able to learn about the real behaviors and attitudes of seniors, due to the non-linear and multi-criteria course of aging [Iwański 2017]. Hence, research taking into account the thresholds of old age will be more valuable [Szarota 2004]. An example of the first such research conducted among Polish seniors who use and do not use ICT, is the research by Dąbrowska, Janoś-Kresło and Mróz. The authors used the following age ranges: 60-64 years, 65-69 years and 70 years and more.

It is worth emphasizing at this point the importance of the qualitative approach, which, in particular with regard to the elderly, allows for understanding the reasons for the lack of interest, but also the involvement or abandonment of ICT.

As can be seen from the data in Table 1, the proportion of seniors who use ICT is significantly lower than that of the general population and applies to all four levels of IS development. It should be assumed that the reasons for this state of affairs are complex, consisting of economic, health, but also social and personality factors. For example, an important feature of modern seniors, represented by the BB (baby boomer) generation, is that they are used to consuming a lot. It is difficult for them to change their current habits. They don't see themselves as older, on the contrary: they want to feel, believe and be treated like younger people [Augus and Westbrook 2019]. They ignore their calendar age, reject a passive attitude towards the aging process, take an interest in and buy things similar to younger people.

It should also be assumed that the next generations of seniors, now 50, will be characterized by a high level of ICT ownership, based on the variety of devices and systems they use today. It remains unclear whether and to what extent they will continue to use them, if and why they will want to use (or not) the new ICT. Such questions seem justified in the context of the expected further expansion of ICT in areas such as administration or health.

\section{DISCUSION AND CONCLUSION}

New technologies strongly interfere in everyday life and it is reasonable to assume that it will become increasingly difficult or even impossible to function in society without having the appropriate knowledge and skills to use them. The variable that most determines the access, extent and use of new technologies is calendar age [Marston et al. 2016]. Hence, seniors are still perceived as reluctant to try new technologies, struggling to learn how to use the tools belonging to new media [Bąk and Hołda 2013], and thus often overlooked as recipients of digital content [Gacka 2017]. Meanwhile, one of the features of the information society is to provide its citizens, including the elderly, with access to and the ability to use new technologies so as to benefit from a variety of services that will result in a higher quality of life [Dabrowska et al. 2020, pp. 15-16].

Contrary to stereotypes, older people are a heterogeneous group of consumers, although at the same time, due to their calendar age, they are characterized by different needs from younger people, but also opportunities to use goods or services due to changes in the human body with the passing of the years.

One should fully agree with Jóźwiak and Kotowska [2010] that population aging is an inevitable and irreversible process. It is necessary to recognize its existence, to try to predict its course and to win the challenges created by taking appropriate adaptation, anticipation and modernization actions. Their effectiveness will also be determined by the stakeholders themselves through their acceptance or rejection. Therefore, it is important to study the needs, behaviour and attitudes of older people.

Due to the high dynamics of introduced modifications and the number of new ICT products, as well as their expected further expansion, it should be assumed that research on the determinants of acceptance of novelties in the field of ICT will constitute one of the most important challenges for companies and other organisations operating in ageing societies. Thus, a new area of knowledge, which is gerontechnology from the perspective of creating goods and services adapted to the capabilities of seniors, in the physical, ergonomic sense, as well as in the form of completely new solutions corresponding to the newly discovered needs and aspirations of the elderly, gains importance [Jurek 2012, p. 171]. 


\section{REFERENCES}

Augus, A., Westbrook, G. (2019). Top 10 Global Consumer Trends 2019, Euromonitor International, 6-12. Retrieved from https://go.euromonitor.com/white-paper-EC-2019Top-10-Global-Consumer-Trends.html\#download-link [accessed 01.05.2021].

Avramow, D., Maskova, M. (2003). Active Ageing in Europe, vol. 1, Population Studies no 41. Council of Europe Publishing, Strasburg.

Badowska, S. (2016). Innowacyjność konsumentów seniorów w świetle badań własnych. Zarządzanie i Finanse/ Journal of Management and Finance 14(1), 65-85.

Badowska, S., Rogala, A. (2016). Konsumencka innowacyjności a zachowania konsumentów seniorów - wyniki badań. Problemy Zarządzania 14/2(1), 204-223.

Bąk, A., Hołda, M. (2013). Seniorzy w sieci. Między stereotypem a prawdą (Seniors on the web. Between the stereotype and the truth). [In:] M. Wysocka-Pleczyk, B. Świeży (Eds), Człowiek zalogowany. Od mowy nienawiści do integracji w sieci. Biblioteka Jagiellońska, Kraków, 131-138.

Batsaikhan, U. (2017). Embracing the silver economy. Retrieved from http://bruegel.org/2017/04/embracing-thesilver-economy/ [accessed 1.04.2019].

Bell, D. (1976). Cultural contradictions of capitalism. Basic Books, New York.

Błędowski, P. (2002). Lokalna polityka społeczna wobec ludzi starszych. SGH, Warszawa.

Błędowski, P., Dzięgielewska, M., Szatur-Jaworska, B. (2012). Podstawy gerontologii społecznej. Aspra, Warszawa.

Bombol, K., Słaby, T. (2011). Konsument 55+ wyzwaniem dla rynku. SGH, Warszawa.

Casey, M. (2001). Europejska polityka informacyjna: wyzwania i perspektywy dla administracji publicznej. Wydawnictwo Uniwersytetu im. M. Kopernika, Toruń.

Castells, M. (1996). The information age: economy, society and culuture. Blackwell Publishers, Oxford.

Castells, M. (2007). Społeczeństwo sieci. Wydawnictwo Naukowe PWN, Warszwa.

Czaja, S. (2010). Spory wokół pojęcia społeczeństwa informacyjnego i gospodarki opartej na wiedzy - problemy identyfikacji i pomiaru. Prace Naukowe UE we Wrocławiu, Ekonomia 10, 139, 39-55.

Dąbrowska, A., Janoś-Kresło, M., Mróz, B. (2020). Zachowania osób starszych na rynku e-usług. Oficyna Wydawnicza SGH, Warszawa.

Drucker, P. (1993), Post-capitalist society, Elsevier, Oxford.

Dziuba, D.T. (2001). Nurt ekonomiczny w badaniach społeczeństwa informacyjnego. Ekonomia 1, 140-152.
Eurostat (2021). Database. Retrieved from https://ec.europa. eu/eurostat/web/digital-economy-and-society/data/database [accessed 07.05.2021].

Gacka, J. (2017). Polscy seniorzy w sieci: wirtualna złota jesień? Korzystanie przez osoby dojrzałe z Internetu i nowych technologii. Konteksty Społeczne 5, 1(9), 84-91.

Goliński, M. (2009). Spór o pojęcie społeczeństwa informacyjnego. Roczniki Kolegium Analiz Ekonomicznych 20, 61-77.

Goliński, M. (2013). Społeczeństwo informacyjne - geneza koncepcji i problematyka pomiaru. Monografie i Opracowania 580. Oficyna Wydawnicza SGH, Warszawa.

GUS (2021). Sytuacja osób starszych w Polsce w 2019 r. The situation of elderly people in Poland in 2019. Analizy statystyczne GUS, Białystok. Retrieved from https:// stat.gov.pl/download/gfx/portalinformacyjny/pl/defaultaktualnosci/6002/2/2/1/sytuacja_osob_starszych_w_ polsce_w_2019_roku.pdf [accessed 05.07.2021].

Hough, M., Kobylanski, A. (2009). Increasing elder consumer interactions with information technology, Journal of Consumer Marketing 26(1), 39-48.

Howe, N. (2018). The Greying of Wealth. Forbes, 16 march. Retrieved from https://www.forbes.com/sites/neilhowe/2018/03/16/the-graying-of-wealth/\#535830c302da [accessed 01.04.2019].

Iwański, R. (2017). Nowe oblicza starości z perspektywy dalszego starzenia się populacji. Studia Oeconomica Posnaniensia 5, 11, 113-128.

Jóźwiak, J., Kotowska, I.E. (2010). Przewidywane zmiany liczby i struktury wieku ludności w Polsce do 2035 r. i ich skutki ekonomiczne. [In:] E. Mączyńska (Ed.), Problemy demograficzne polski i ich skutki ekonomiczne. Raport z pierwszego posiedzenia Narodowej Rady Rozwoju. Kancelaria Prezydenta Rzeczpospolitej Polskiej, Warszawa, 40-55.

Jurek, Ł. (2012). Ekonomia starzejącego się społeczeństwa. Difin, Warszawa.

Kęsy, M. (2011). Społeczeństwo informacyjne w rozwoju cywilizacyjnym ludzkości, Dydaktyka Informatyki 6, 74-92.

Krzysztofek, K., Szczepański, M.S. (2005). Zrozumieć rozwój. Od społeczeństw tradycyjnych do informacyjnych. Wydawnictwo Uniwersytetu Śląskiego, Katowice.

Kusińska, A. (Ed.) (2002). Warunki życia osób starszych i ich zachowań rynkowych. Instytut Rynku Wewnętrznego i Konsumpcji, Warszawa.

Marston, H.R., Kroll, M., Fink, D., de Rosario, H., Gschwind, Y.J. (2016). Technology use, adoption and behavior in older adults: Results from the iStoppFalls project. Educational Gerontology 42(6), 371-387. 
Mossakowska, M., Więcek, A., Błędowski, P. (Eds) (2012). Aspekty medyczne, psychologiczne, socjologiczne i ekonomiczne starzenia się ludzi w Polsce. Termedia Wydawnictwa Medyczne, MIBMIK, Poznań.

OECD (2018). Average Effective Age of Retirement Versus the Normal Retirement Age. Retrieved from https:// www.oecd.org/els/emp/Summary_values.xlsx [accessed 12.05.2020].

Olejniczak, T. (2019). Konsumenci seniorzy wobec innowacji produktowych. Wydawnictwo Uniwersytetu Ekonomicznego w Poznaniu, Poznań.

Olson, K.E., O’Brien, M.A., Rogers, W.A., Harness, N. (2011). Diffusion of technology: Frequency of use for younger and older adults. Ageing International 36(1), 123-145.

Petrovic, A., Berzelak, J., Burnik, T., Taipale, S., Dolnicar, V. (2018). Investigatigating smartphone acceptance factors among seniors with stryctural equation modeling. Gerontechnology17, 61.

Szarota, Z. (2004). Gerontologia społeczna i oświatowa. Zakres problematyki. Wydawnictwo Naukowe Akademii Pedagogicznej Kraków, Kraków.

Toffler, A. (1985). Trzecia fala. Państwowy Instytut Wydawniczy, Warszawa.
UNFPA and HelpAge International (2012). Ageing in the Twenty-First Century. A Celebration and the Change, New York, London. Retrieved from https://www.unfpa. org/publications/ageing-twenty-first-century [accessed 06.07.2021].

WHO (2004)? Ageing and Health Technical Report Volume 5. A glossary of terms for community health care and services for older persons. WHO Centre for Health Development, Kobe, Japan. Retrieved from https://apps.who. int/iris/handle/10665/68896 [accessed 04.05.2021].

Zacher, L.W. (1992). Społeczeństwo informacyjne. Aspekty techniczne, społeczne i polityczne. Warszfraf, Lublin, Warszawa.

Zacher, L.W. (2007). Transformacje społeczeństw. Od informacji do wiedzy. C.H. Beck, Warszawa.

Zalega, T. (2016). Segment osób w wieku 65+ w Polsce. Jakość życia, konsumpcja, zachowania konsumenckie. Wydawnictwo Naukowe Wydziału Zarządzania Uniwersytetu Warszawskiego, Warszawa.

Zboina, B. (2008). Jakość życia osób starszych. Stowarzyszenie Nauka, Edukacja, Rozwój, Ostrowiec Świętokrzyski.

\section{OSOBY STARSZE JAKO PODMIOT BADAŃ SPOŁECZEŃSTWA INFORMACYJNEGO}

\section{STRESZCZENIE}

Celem artykułu jest przedstawienie zasadności i uwarunkowań prowadzenia badań seniorów oraz wyzwań w kontekście dalszego rozwoju społeczeństwa informacyjnego (SI). Prowadzone rozważania prowadzą do wniosku, że takie badania już z natury są ograniczone brakiem jednoznaczności pojęć osoba starsza i społeczeństwo informacyjne. Mimo to argumentuje się, że badania osób starszych jako członków SI są w pełni uzasadnione znaczeniem tej grupy w społeczeństwie ogółem. Prowadzenie badań w grupach wiekowych 60 lat i więcej lub 65 lat i więcej jest niewystarczające. Osoby starsze powinny być analizowane w mniejszych przedziałach wiekowych z wykorzystaniem zarówno podejścia ilościowego, jak i jakościowego. Te drugie pozwalają na zrozumienie przyczyn korzystania i odrzucania nowych technologii, co pozwoli w przyszłości na realizację celu rozwoju SI w postaci wzrostu jakości życia seniorów.

Słowa kluczowe: osoby starsze, badania seniorów, społeczeństwo informacyjne 